\title{
Journal of Earth and Environmental Science Research
}

\section{Combat the Global Warming by Generating Renewable Sources of Energy}

\author{
P. N. Darde, Mish \\ Professor and HOD (CIVIL), Jaipur National University, Jagatpura, Jaipur, Rajasthan India
}

\begin{abstract}
Global warming is the increase in average temperature of thetheearth's surface air and oceans. Most of the observed temperature increase is caused by increased concentration of greenhouse gases. Major gases are water vapor (36-70\%), carbon dioxide (9-26\%), Methane (4- $9 \%$ ) and Ozone (3- 7 \%).

Electricity generation accounts for more than $50 \%$ Global Warming emission (8) with the majority generated by coal fired power plants in the world. Natural gas power plants produce more than $10 \%$ total emission on the earth. In contrast to this most renewable energy sources produce very little global warming effects.

The natural gas emits $\mathrm{CO}_{2}$ between 0.6 to 2 pounds carbon dioxide equivalents / $\mathrm{kwh}$, coal emits $\mathrm{CO}_{2}$ between 1.4 to 3.6 pounds equivalents $/ \mathrm{kwh}$. Wind emits 0.02 to 0.04 pounds of $\mathrm{CO}_{2} / \mathrm{kwh}$. Solar emits 0.07 to 0.2 pounds $\mathrm{CO}_{2} / \mathrm{kwh}$, Geothermal 0.1 to 0.2 pounds/ kwh, and hydro power 0.1 to 0.5 pounds $\mathrm{CO} / \mathrm{kwh}$. (8) Electricity generation from Biomass can have a wide range of Global Warming Emission depending on methods of harvesting. Thus the supply of renewable energy would allow us to replace carbon intensive energy sources significantly in the world.
\end{abstract}

Here in this article the author has made an attempt to bring out the status of renewable sources of energy like Hydro power, Solar and Wind energy and their contribution to combat the effects of environmental degradation. A special emphasis has been given in respect of Indian context.

\section{*Corresponding author}

P. N. DARDE, MISH, Jaipur National University, Jagatpura, Jaipur, Rajasthan India. phone: +91 8527681923; Email:pndarde@rediffmail.com

Received: July 13, 2019; Accepted: July 25, 2019, Published: Aug 03, 2019

Keywords: Renewable; Emits; Wind; Harvesting; Warming

\section{Importance of Energy}

In modernday's power sector is the most important sector for the economical growth and prosperity of any country. However human activitiesover loadingatmosphere with carbon dioxide and other global warming emission which trap heat steadily andincreases the planets temperature and creates significant harmful impacts on our health, environment and climate. Electricity production accounts for more than $50 \%$ global warming emission with the majority generated by coalfired power plants, natural gas power plants produce more than $10 \%$ total emission in the world. In contrast to this most renewable energy sources produce very littleglobal warming emission [1-5].

\section{Background}

Consumption of Various Sourcs of Energy

Table I: Percentage Utilization of Various Sources of Energy

\begin{tabular}{|c|c|c|}
\hline Sr. No. & Sources & Percentage Utilizations \\
\hline 1 & Oil & 38.3 \\
\hline 2 & Coal & 32.5 \\
\hline 3 & Gas & 19.0 \\
\hline 4 & Wood & 6.5 \\
\hline
\end{tabular}

\begin{tabular}{|c|c|c|}
\hline 5 & Hydro power & 2.0 \\
\hline 6 & Dung & 1.2 \\
\hline 7 & Waste & 0.3 \\
\hline 8 & Uranium & 0.13 \\
\hline
\end{tabular}

There is alarming effect of generation of energy from various sourceson the climate change and global warming, speciallyoil, gas, and coalwhich produce carbon dioxide.

The comparison of emission of Carbon Dioxide by various sourcesis as under.

Table 2: Comparision

\begin{tabular}{|l|c|c|}
\hline Sr.No. & Sources of Energy & Emission of $\mathrm{CO}^{2}$ in $\mathrm{kg}$ equivalent $/ \mathrm{kW}$ \\
\hline 1 & Natural Gas & 0.272 to 0.9 \\
\hline 2 & Coal & 0.635 to 1.63 \\
\hline 3 & Wind Energy & 0.009 to 0.018 \\
\hline 4 & Solar & 0.031 to 0.09 \\
\hline 5 & Geothermal & 0.0453 to 0.09 \\
\hline 6 & Hydropower & 0.0453 to 0.2268 \\
\hline
\end{tabular}

The carbon produced from 1990 to 2025 by various countries is presented in thegraph. 


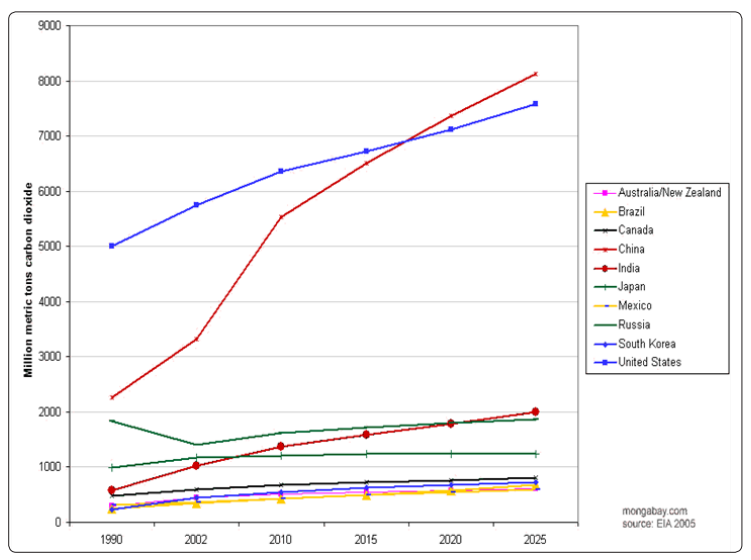

Figure 1: World Carbon Dioxide Emissions by Country, 19902025 (Source-Google web)

Electricity generation from Biomass can have a wide range of Global Warming Emission depending on methods. Thusthe supply of renewableenergy would allow us to replace Carbon Intensive energy sources significantly in the world [6-10].

\section{Reasons To Harness Renewables \\ Cost Comparison}

The cost of the renewable sources are decreasing steadily and have been projected to drop in future. The average price of solar panel has dropped almost $60 \%$ in the last 5 years. The cost of energy from wind has dropped by $20 \%$ in the last five years. The cost is likely to decline further by introduction of new technology. In contrast the cost of fossil fuel in increasing day by day.

\section{Shortages of Power}

There is huge shortage of power during peak hours, during morning and evening hours. For this a storage type hydroprojects are required to be developed to balance the frequency in the system.

\section{Public Health Benefits}

Generating Electricity from renewable energy sources offers significant public health benefits. The air and water pollution emitted by coal and natural gas plant is linked to breathing problems, neurological damages, heart attacks and cancer. Replacing fossil fuel by renewable energy has been found to reduce premature mortality and lost work days.

Wind,Solar, and Hydro system generate electricity with no associated air pollution emission. Wind and solar energy require no water to operate and hence do not pollute water resources. As such do not interfere with agriculture, drinking water, and other important water needs. Jobs and other economic benefits are very high in developing renewable energyas compared to Coal and Gas fired system. Fossil fuel technology hasmore capital intensive and renewable energy are more labour intensive [11-15].

\section{Renewable Sources of Energy \\ Hydro Electric Power In India}

India is the $7^{\text {th }}$ largest producer of hydro electric power. The hydropower potential of $84,000 \mathrm{MW}$ at $60 \%$ load factor is one of the largest in the world. The present installed capacity as on $31^{\text {St }}$ March 2016 is $42,783 \mathrm{MW}$ which is $14.35 \%$ of total utility electricity generation in India. In addition $6780 \mathrm{MW}$ small hydro power installed as on $31^{\text {St }}$ March 2016 which includes mini, micro and small hydro. (less than $25 \mathrm{MW}$ ). India also imports surplus power from Bhutan. The hydro power plant at Darjeeling and Shivanasamudra were established in 1898 and 1904 respectively.
They were among the first in Asia. Also 56 pumped storage schemes with an aggregate capacity of 94,000 MW have been identified.

National Hydroelectric power Corporation, North East Electric Power Corporation, (NEEPCO), Satluj Jal Vidyut Nigam, (SJVNL), THDC and NTPC Hydro. are a few public sector companies engaged in development of Hydro Power. Private Sector owns only $7.5 \%$ out of the total $42,783 \mathrm{MW}$, Bhakra Beas Management Board (BBMW) in North India has an installed capacity of $2.9 \mathrm{GW}$ and generates 12000-14000 million units per year. The generation cost after 4 decadesis 20 paisa per Kwh. BBMW is major source of peaking power. BBMW reservoir annually supplies water for irrigation toabout 6 million Hectares of agriculture land [16-17].

\section{The Hydroelectric Generations in Various Countries}

The hydroelectric generation in various countries is shown in table-II

Table 3: Hydro Potential in India

\begin{tabular}{|l|c|c|c|}
\hline Continents & $\begin{array}{c}\text { Technical } \\
\text { Potentials(I) }\end{array}$ & $\begin{array}{c}\text { Generated in } \\
\mathbf{1 9 9 0 ( I I )}\end{array}$ & $\begin{array}{c}\text { (II) as \% 0f } \\
\text { (I) }\end{array}$ \\
\hline Africa & 1344 & 50 & 3.7 \\
\hline Asia & 4212 & 387 & 9.2 \\
\hline Austrilia & 203 & 38 & 18.7 \\
\hline Europe & 836 & 483 & 57,8 \\
\hline North America & 969 & 573 & 59.1 \\
\hline Latin America & 3486 & 380 & 10.9 \\
\hline USSR & 2950 & 223 & 7.6 \\
\hline World & 14000 & 2134 & 15.2 \\
\hline
\end{tabular}

According to United Nations Estimates in1981 the total world hydropower production would have risen to $80 \%$ by 2020 .

\section{Hydro Potential in India}

India is blessed with immense amount of hydroelectric potential and ranks 5 th in terms of exploitable hydro potential on global scenario. As per assessment made by CEA (Central Electricity Authority ) India is endowed with economically exploitable hydro power potential to the extent of $148700 \mathrm{MW}$ of installed capacity. The basin wise assessed potential is as under.

Table 4: Basin wise Potentail

\begin{tabular}{|c|l|l|}
\hline Sr.No. & Places & Potential in MW \\
\hline 1 & Indus basin & $33,832 \mathrm{MW}$ \\
\hline 2 & Ganga Basin & 20,711 MW \\
\hline 3 & Central Indian River Basin & $4,152 \mathrm{MW}$ \\
\hline 4 & $\begin{array}{l}\text { Western Flowing River of Southern } \\
\text { India }\end{array}$ & $9,430 \mathrm{MW}$ \\
\hline 5 & $\begin{array}{l}\text { Eastern Flowing Rivers of Southern } \\
\text { India }\end{array}$ & $14,511 \mathrm{MW}$ \\
\hline 6 & Bramhaputra Basin & $66,065 \mathrm{MW}$ \\
\hline 7 & Total & $\mathbf{1 , 4 8 7 0 1}$ \\
\hline
\end{tabular}

Thus India is endowed with 2,50,000 MW of hydro potentials. And Total installed capacity from hydro power is $36,878 \mathrm{MW}$.

\section{Small Hydro Power}

Small hydro projects up to the capacity of $25 \mathrm{MW}$ have been 
classified as small hydro projects under the Ministry of Renewable and New Sources of Energy Govt of India. It has a potential of 15000 MW. They can supply energy to remote and hilly areas where extension of grid power system is either not possible or is unsuccessful. These projects are environmentally begnin and have short gestation period.

The account of total capacity of small hydro projects below 25 MW is given below in Table-5

Table 5: Small Hydro Potential [12]

\begin{tabular}{|l|c|c|}
\hline Project status & $\begin{array}{c}\text { Total no of } \\
\text { projects }\end{array}$ & $\begin{array}{c}\text { Total capacity in } \\
\text { MW }\end{array}$ \\
\hline Commissioned & 556 & 2767 \\
\hline Under Implementation & 203 & 468 \\
\hline Total & 759 & 3235 \\
\hline
\end{tabular}

Of all the non-conventional sources of energy, small hydro represents the highest density source and stands first in terms of energy generation. Most of small hydro power projects are grid connected.

Global installed capacity of small hydro power project is 50,000 MW against estimated potential of 18, 00,000 MW.

Investment of small hydro is affordable to private sectors enabling quick electricity and economic returns. Fiscal investment by central Govt is attracting private initiatives in this field.

In Arunachal alone there are numbers of small hydro projects such as Kamang (6MW), Sippi (3MW), Jugdin (1MW) which have been commissioned and supplying power to people in remote areas. The cost of energy is ranging from 4.43 to 6.0 per unit which is quite reasonable. Their development has forbidden the use of forest wood and use of costly diesel energy protecting the environment from pollution.

\section{Wind Energy}

Wind power is another source of energy. 1973 herald the definite breakthrough in harnessing the wind energy. In India the program was started in 1983-84 with the efforts of the Ministry of Nonconventional Sources of Energy. The estimated potential of wind power is $20,000 \mathrm{MW}$ in the country. It has been revised to $45,195 \mathrm{MW}$ considering the technological advances and availability of more modern equipment. India ranked fifth in the world after Germany, USA, Denmark and Spain.

A long range program has been initiated in the direction of wind energy generation and formation of wind form.

The global scene of wind energy is mentioned below (2006)

Table 6: Global Potential of Wind Energy

\begin{tabular}{|c|c|c|}
\hline Sr.No. & Country & Potential in MW \\
\hline 1 & America & 1690 \\
\hline 2 & Germany & 1300 \\
\hline 3 & Rest of Europe & $149 / 84$ \\
\hline 4 & India & 1269.1 \\
\hline
\end{tabular}

State wise distribution in India is in Table-7
Table 7: State wise wind energy

\begin{tabular}{|c|c|c|}
\hline Sr. No. & State & Potential in MW \\
\hline 1 & Gujarat & 130 \\
\hline 2 & Andhra & 52.5 \\
\hline 3 & Madhya Pradesh & 8.03 \\
\hline 4 & Tamil Nadu & 1065 \\
\hline 5 & Others & 11.57 \\
\hline 6 & Total & 1269.1 \\
\hline
\end{tabular}

Out of 1269.1 MW,736. 326 MW has been connected to grid. About 24-25 manufacturers are engaged in assembly and production of wind turbines. A national wind Test Centre has been established in Tamilnadu, South India with the assistance of UNDP (United Nations Development Program).

The capacity factor of the wind form is in the range of $14 \%$ only. In some cases it goes down to $10 \%$. Therefore very careful site selection is called for the improvement of capacity factor. The unit size of wind turbine has gone from 55 to $100 \mathrm{~kW}$ in the first few projects to $2.1 \mathrm{MW}$ in recent projects. The capital cost of wind power ranges from Rs 4 to Rs 5 crore per MW which is very reasonable as compared to conventional sources of energy.

\section{Solar Power}

Solar as an idea emerged many times earlier. In our galaxy Sun is the medium size star. It is a glowing fire ball consisting of hot gaseous matter notably hydrogen and helium. The sun radiates 53 million watts of energy per square meters of its surface. The earth receives $17 \times 1012 \mathrm{~kW}$ of energy (1,70 00,000 million MW). The vast amount of energy received forms the basis of all lives on the earth. The special distribution of solar radiation on the earth is greatly influenced by location, climate and atmospheric conditions. India receives about 300 clear sunny days in a year of solar radiation or about 4 to $7 \mathrm{~kW}$ per sq $\mathrm{m}$ depending on location. The solar energy is much more than the total annual requirement.

It has been estimated that a potential of $20 \mathrm{MW} / \mathrm{sq} \mathrm{km}$ through photovoltaic route and $35 \mathrm{MW} / \mathrm{sq} \mathrm{km}$ by solar thermal source is available. Solar power has been utilized as stand alone and grid connected power system has been under use. The stand alone application include street light, domestic light, portal solar lanterns, water pumps etc.by using principle of conversion of solar energy directly in to electricity.

To exploit the solar energy, Govt. has launched a twin program for solar energy development. The Ministry of New and Renewable Energy has initiated the solar photovoltaic (SPV) and solar thermal power program. The SPV modes generate the DC (Direct Current) and convert it in to AC (Alternate) quality power. The solar thermal power module uses the concentrated solar power to increase the temperature of working fluid above $300^{\circ} \mathrm{C}$ to run the conventional turbines to generate energy.

In order to promote use of solar energy in accelerated rate, Prime Minister has launched Jawaharlal Nehru National Solar Mission on January 2010. The tariff has been fixed at Rs 14.95 solar PV and Rs 12.85 for solar thermal [2].

It is estimated that the $\mathbf{1 k W}$ solar plant offsets about $=\mathbf{0 . 7 3}$ tons of $\mathrm{CO}_{2}$ emissions.

So a 1 MW solar plant will offset $=\mathbf{7 3 0}$ tons of $\mathrm{CO}_{2}$ emissions Now a tree can absorb as much as $=\mathbf{2 2} \mathbf{~ k g}$ of $\mathrm{CO}_{2}$ a year. So going solar will offset planting around $730,000 / 22=\mathbf{3 3}, \mathbf{1 8 3}$ trees. 
(Google search)

Well, that's a lot of trees being offset with a $1 \mathrm{MW}$ solar plant. Which is why all of us have to come together in reducing the carbon emissions we all make and take respective measures to use other renewable sources of electricity.

You have the luxury of walking down freely on the road, but a few years from now you would regret seeing your children play with a breathing mask on their face.

Table 8: Total Solar Energy Potential

\begin{tabular}{|l|c|c|}
\hline Project status & Total no of projects & Total capacity in MW \\
\hline Commissioned & 556 & 2767 \\
\hline $\begin{array}{l}\text { Under } \\
\text { Implementation }\end{array}$ & 203 & 468 \\
\hline Total & 759 & 3235 \\
\hline
\end{tabular}

Table 9: Total Potential of Renewables and Decrease of $\mathrm{CO}_{2}$

\begin{tabular}{|c|c|c|c|}
\hline Sr.No. & Projects & Potentials & $\mathbf{C O}_{2}$-offsets \\
\hline 1 & Hydro Power & $84000 \mathrm{MW}$ & 61320 tons \\
\hline 2 & Small hydro & $20000 \mathrm{MW}$ & 14600 tons \\
\hline 3 & Wind Power & $20000 \mathrm{MW}$ & 14600 tons \\
\hline 4 & Solar Power & 3235 & 2361.55 tons \\
\hline
\end{tabular}

1 MW power can offset planting of 3183 trees ayear.

In India Harnessing all hydro power, wind, and solar can reduce the carbon by $92,881.55$ tons in the atmosphere.

\section{Conclusions}

- The sources of renewable energy are available in plenty. However they are yet to be harness.

- They cost effectives and environmental friendly.

- Follow the Kyoto Protocol

- Make use of carbon credits

- $\quad$ Reduce, reuse and use recycle

- $\quad$ Reduce the use of thermal power plants.

- Use renewable energy.

\section{References}

1. Ajit Gupta (2000) 'International conference on accelerating grid based renewable power generation for clean environment', policy approaches,

2. Akshya Urja (2010)Water and Energy.

3. C BSmith (1981) Energy Management Principles: Pergaman Press.

4. CBIP New Delhi (2010) Water and Energy, 67: 8

5. CBIP, Manual on Small Hydro (2013)

6. Dandekar and Sharma (2017) Water Power Engineering, Vikas Publishing house, N Delhi

7. Green Energy (2009) World Institute of Sustainable energy, Punevol 5:3.

8. Institute of Economic Studies (2016)

9. Jyoti Parikh (1980) Energy system and development, Oxford University.

10. MNES, Report (2005-2006).

11. NHPC (2000)Sippi Small Hydro project, DPR.

12. PS Nigam (1979) Hand book, Design of Hydroelectric Power Structures, Nem Chand and bros Roorkee.

13. RS Varshney (2014) Hydropower Structures, Roorkee Publication Vol: 3.

14. SN Singh (1979) Energy conversion and storage, JIE (India) Vol 59.

15. SP Sukhatme (1997) Solar Energy, Tata McGraw-Hill, Delhi.

16. TERI (2010) News letter

17. USAID (2016) New Delhi report, Advancing co generation in the Indian Sugar Industries

18. UNDP (2000) World Energy Assessment, Energy and the challenges of sustainability.
Copyright: C2019 P. N. DARDE, MISH. This is an open-access article distributed under the terms of the Creative Commons Attribution License, which permits unrestricted use, distribution, and reproduction in any medium, provided the original author and source are credited. 